\title{
KEMAMPUAN BERPIKIR KREATIF MATEMATIKA MATERI KUBUS DAN BALOK SISWA MTsN 1 MAKASSAR
}

\author{
Mutmainah* $^{*}$ \\ Program Studi Pendidikan Matematika, STKIP Bima \\ *Email korespondensi: mutmainahmbojo23@gmail.com
}

\begin{abstract}
ABSTRAK
Penelitian ini bertujuan mengungkap kemampuan berpikir kreatif matematika siswa yang mencakup indikator kelancaran (fluency), fleksibilitas, dan kabaruan (originality) dengan cara mendeskripsikan jawaban siswa dalam menyelesaikan soal kubus dan balok. Penelitian ini dilaksanakan pada siswa kelas VIII unggulan MTsN 1 Makassar yang berjumlah 39 siswa. Subyek penelitian diambil sebanyak 6 orang dengan menggunakan kriteria tingkatan kelompok tinggi, sedang, dan rendah masing-masing 2 siswa setiap tingkatan. Instrumen yang digunakan adalah tes kemampuan berpikir kreatif yang berjumlah 4 butir soal uraian dengan analisis deskriptif kualitatif. Hasil penelitian menunjukkan bahwa kemampuan berpikir kreatif matematika siswa mencakup ketiga indikator tersebut sangat bagus berdasarkan nilai persentasi dari masing-masing indikator berada diatas $50 \%$. Pada indikator kelancaran nilai persentasenya sebesar $100 \%$ soal nomor 1 dan $95,83 \%$ soal nomor 2 , nilai persentase indikator fleksibilitas pada soal nomor 2 dan 4 masing-masing adalah 95,83\% dan 91,67\%, dan nilai persentase indikator kebaruan pada soal nomor 2 dan 4 masing-masing adalah $75 \%$ dan 70,83\%. Dari ketiga indikator di atas, nilai persentase kemapuan berpikir kreatif siswa rendah jika dibandingkan kedua indikator lainnya, hal ini menunjukkan bahwa siswa kurang mampu dalam menghasilkan jawaban/gagasan yang tidak biasanya dan kesesuaian jawaban yang diberikan sangat tidak relevan dengan masalahnya.
\end{abstract}

Kata kunci: kemampuan berpikir kreatif matematika, materi kubus dan balok.

\begin{abstract}
This study aims to reveal students' mathematical creative thinking skills which include indicators of fluency, flexibility, and originality by describing students' answers in solving cube and block problems. This research was conducted on the superior grade VIII students of MTsN 1 Makassar, totaling 39 students. The research subjects were taken as many as 6 people using the criteria for high, medium, and low group levels, each 2 students at each level. The instrument used is a creative thinking ability test, which consists of 4 items of description with qualitative descriptive analysis. The results showed that the students' mathematical creative thinking skills including the three indicators were very good based on the percentage value of each indicator being above $50 \%$. In the fluency indicator, the percentage value is $100 \%$ for item number 1 and $95.83 \%$ for question number 2, the percentage value of the flexibility indicator for item number 2 and 4 is $95.83 \%$ and $91.67 \%$, respectively, and the percentage value of the novelty indicator is questions number 2 and 4 are $75 \%$ and $70.83 \%$, respectively. From the three indicators above, the percentage value of students' creative thinking ability is low when compared to the other two indicators, this shows that students are less able to produce unusual answers/ideas and the suitability of the answers given is very irrelevant to the problem.
\end{abstract}

Keywords : Mathematical creative thinking skills, cube and block. 


\section{PENDAHULUAN}

Matematika merupakan cabang ilmu pengetahuan yang memiliki peranan penting dalam kemajuan teknologi. Selain itu, matematika merupakan bagian dari aplikasi kehidupan sehari-hari seperti mengukur, berhitung, transaksi jual beli, dan lain sebagainya. Menurut Amidi \& Zahid (2016), matematika harus diberikan sejak dari satuan pendidikan dasar hingga menengah dengan harapan peserta dapat memahami konsep matematika sejak dini, serta dapat mengaplikasikan konsep matematika dalam kehidupan sehari-hari. Adapun Mikrayanti (2020) menyatakan bahwa penguasaan terhadap matematika menjadi sarana yang ampuh dalam mempelajari bidang ilmu yang lain, baik pada jenjang pendidikan yang sama maupun pada jenjang yang lebih tinggi.

Jumramiatun, Sowanto, \& Mikrayanti (2020) menyatakan bahwa matematika sering diartikan sebagai pembelajaran yang dianggap sulit sehingga siswa kesulitan dalam menyelesaikan soal matematika. Adapun menurut Mulyadin, Sowanto, \& Dusalan (2020) yang menyatakan bahwa pada umumnya guru terlalu berkonsentrasi pada latihan menyelesaikan soal yang lebih bersifat prosedural mekanistis dari pada menanamkan pemahaman. Berdasarkan kedua pendapat di atas, maka dapat dikatakan bahwa hal ini terjadi karena guru masih kurang mampu untuk mendesain soal-soal/permasalahan matematika yang mampu mengkonstruksi cara berpikir kreatif siswa dalam menghasilkan solusi yang tepat. Dengan kata lain guru, lebih menekankan pada hafalan rumus dan menghitung untuk menyelesaikannya.

Dalam pembelajaran matematika, guru dapat mengembangkan pembelajaran yang melibatkan pemikiran divergen dalam mengasah kemampuan berpikir kreatif siswa (Fardah, 2012). Guru dapat mendesain tugas atau tes berbentuk masalah matematika dengan mengacu pada indikator-indikator kemampuan berpikir kreatif. Karena sebagaimana yang dijelaskan oleh Rudyanto (2014) bahwa kurangnya kemampuan berpikir kreatif ini disebabkan guru jarang atau bahkan tidak pernah melakukan pembelajaran yang mengarah pada kemampuan berpikir kreatif. Menurut Meika \& Sujana (2017) menyatakan kreativitas atau berpikir kreatif tidak bisa muncul dengan sendirinya melainkan butuh suatu latihan. Dalam hal ini guru harus bisa melatih dan mengasah kemampuan berpikir kratif siswa dengan pembelajaran yang memunculkan permasalahan sehari-hari yang bersifat tidak rutin. Adapun menurut Susilowati, Pujiastuti, \& Sukirwan (2020) menyatakan bahwa terbentuknya kemampuan 
berpikir kreatif pada pribadi siswa, akan membuat pembelajaran matematika yang dianggap sulit bertahap akan menjadi pelajaran yang menyenangkan, karena dengan berpikir kreatif siswa dapat menyelesaikan permasalahan dengan cara sendirinya tanpa adanya pemikiran yang terfokuskan dengan satu penyelesaian.

Menurut Amidi \& Zahid (2016) menyatakan bahwa kemampuan berpikir kreatif matematis adalah kemampuan menemukan solusi bervariasi yang bersifat baru terhadap masalah matematika yang bersifat terbuka secara mudah dan fleksibel, namun dapat diterima kebenarannya. Arista \& Mahmudi (2020), menyatakan bahwa orang yang memiliki kemampuan berpikir kreatif dapat dicirikan dari rasa keingintahuan yang dimilikinya dan kemampuannya dalam mengeksplorasi beragam pendekatan, cara, atau metode untuk menyelesaikan suatu masalah yang bersifat baru. Adapun menurut Darwanto (2019), berpikir kreatif adalah aktivitas mental yang terkait dengan kepekaan terhadap masalah, mempertimbangkan informasi baru dan ide-ide yang tidak biasanya dengan suatu pikiran terbuka, serta dapat membuat hubungan-hubungan dalam menyelesaikan masalah tersebut.

Untuk dapat mengembangkan kemampuan berpikir kreatif matematis siswa diperlukan keselarasan kreativitas dari unsur-unsur pendidikan metematika, terutama guru sebagai pengajar yang dituntut dapat menghidupkan dan menstimulus siswa dalam berpikir kreatif. guru disamping memberikan motivasi juga harus mampu memberikan ide dan gagasan yang relatif berbeda sehingga siswa mampu menemukan sesuatu yang baru disetiap proses pembelajarannya (Dewi \& Afriansyah 2018). Adapun menurut Ulandari, dkk (2019), kemampuan berpikir kreatif adalah kemampuan untuk menciptakan sesuatu yang baru yang berbeda dari yang lain, memecahkan masalah, dan menciptakan solusi serta membuat rencana inovatif dengan mempertimbangkan masalah yang kemungkinan akan timbul dan bagaimana cara mengatasinya sehingga dalam pelaksanaannya dilakukan secara matang.

Berdasarkan pendapat-pendapat di atas, maka dalam penelitian ini, untuk mengukur krmampuan berpikir kreatif matemtika siswa menggunakan tiga indikator yang mencakup (1) aspek kelancaran (fluency), (2) aspek fleksibilitas, (3) keaslian (originality).

\section{METODE PENELITIAN}

Penelitian ini merupakan penelitian deskriptif kualitatif. Penelitian ini dilaksanakan pada siswa kelas VIII Unggulan MTsN 1 Makassar yang berjumlah 39 siswa. adapun jumlah 
subyeknya sebanyak 6 orang siswa yang ditentukan berdasarkan tingkatan kelompok siswa, yakni kelompok tinggi, kelompok sedang, dan kelompok rendah. Penentuan subyek menggunakan pertimbangan: 1) seleksi hasil tes kemampuan berpikir kreatif; 2) masukan dari guru bidang studi matematika pada saat observasi awal sebelum penelitian; dan 3) kelas VIII Unggulan MTsN 1 Makassar memiliki minat yang tinggi dalam belajar matematika. Data analisis yang dideskripsikan adalah hasil jawaban siswa melalui instrumen kemampuan berpikir kreatif matematika yang mencakup indikator kelancaran (fluency), fleksibilitas, dan kabaruan (originality) materi pokok kubus dan balok yang berjumlah 4 item soal .

\section{HASIL DAN PEMBAHASAN}

Penelitian ini dilaksanakan pada siswa kelas VIII Unggulan MTsN 1 Makassar tahun pelajaran 2016/2017. Data hasil penelitian diperoleh melalui hasil tes kemampuan berpikir kreatif matematis menggunakan instrumen tes berbentuk soal uraian sebanyak 4 butir tes materi kubus dan balok. Adapun instrumen tes mengacu pada indikator-indikator kemampuan berpikir kreatif matematis yang mencakup: Kelancaran (fluency), Fleksibilitas (flexibility), Keaslian (originality). Hasil pengolahan data diperoleh dari 6 orang siswa yang dikelompokkan berdasarkan tingkatan kelompok, yakni kelompok tinggi, kelompok sedang, dan kelompok rendah.

Berdasarkan hasil pengolahan data siswa rekapitulasi data sebagai berikut:

Tabel 1: skor Kemampuan Berpikir Kreatif Matematis

\begin{tabular}{ccc}
\hline \multirow{2}{*}{ Siswa } & \multicolumn{2}{c}{$\begin{array}{c}\text { Skor Kemampuan Berpikir Kreatif } \\
\text { Matematis }\end{array}$} \\
\cline { 2 - 3 } & Fleksibilitas & Keaslian \\
\hline QAA & 4 & 4 \\
AM & 4 & 4 \\
MFAA & 4 & 3 \\
MS & 4 & 3 \\
MNKN & 3 & 2 \\
MF & 4 & 2 \\
Jumlah & 23 & 18 \\
Persentase $(\%)$ & $95,83 \%$ & $75 \%$ \\
\hline
\end{tabular}

Berdasarkan Tabel 1 bahwa kemampuan berpikir kreatif matematis siswa pada soal nomor 1 dengan indikator fleksibilitas berada pada 95,83\%, dan indikator keaslian (originality) dengan persentase $75 \%$. Hal ini menunjukkan bahwa kemampuan berpikir kreatif 
matematis siswa pada indikator fleksibilitas lebih tinggi daripada indikator keaslian (originality).

Tabel 2: skor Kemampuan Berpikir Kreatif Matematis

\begin{tabular}{cc}
\hline Siswa & Kelancaran \\
\hline QAA & 4 \\
AM & 4 \\
MFAA & 4 \\
MS & 4 \\
MNKN & 4 \\
MF & 4 \\
Jumlah & 24 \\
Persentase (\%) & $100 \%$ \\
\hline
\end{tabular}

Berdasarkan Tabel 2 tersebut menunjukan kemampuan berpikir kreatif siswa aspek kelancaran (fluency) pada soal nomor 2 dengan presentase $100 \%$. Dengan demikian kemampuan berpikir kreatif siswa aspek kelancaran sudah sempurna.

Tabel 3: skor Kemampuan Berpikir Kreatif Matematis

\begin{tabular}{ccc}
\hline \multirow{2}{*}{ Siswa } & \multicolumn{2}{c}{$\begin{array}{c}\text { Skor Kemampuan Berpikir Kreatif } \\
\text { Matematis }\end{array}$} \\
\cline { 2 - 3 } & Fleksibilitas & kebaruan \\
\hline QAA & 4 & 4 \\
AM & 4 & 3 \\
MFAA & 4 & 3 \\
MS & 4 & 2 \\
MNKN & 3 & 3 \\
MF & 3 & 2 \\
Jumlah & 22 & 17 \\
Persentase (\%) & $91,67 \%$ & $70,83 \%$ \\
\hline
\end{tabular}

Tabel 3 di atas bahwa kemampuan berpikir kreatif matematis siswa pada soal nomor 3 dengan indikator fleksibilitas berada pada 91,83\%, dan indikator kebaruan (originality) dengan persentase $70,83 \%$. Hal ini menunjukkan bahwa kemampuan berpikir kreatif matematika siswa pada indikator fleksibilitas lebih tinggi daripada indikator kebaruan (originality). Siswa memiliki kemampuan menyelesaikan soal kubus dan balok dengan minimal dua cara yang berbeda dengan nilai jawaban yang sama. Adapun pada aspek 
originalitas menyelesaikan soal nomor 3 tersebut siswa masih mengalami kesulitan disebabkan siswa belum menemukan cara lain yang tidak biasa dilakukannya.

Tabel 4: skor Kemampuan Berpikir Kreatif Matematika

\begin{tabular}{cc}
\hline Siswa & Kelancaran \\
\hline QAA & 4 \\
AM & 4 \\
MFAA & 4 \\
MS & 4 \\
MNKN & 4 \\
MF & 3 \\
Jumlah & 23 \\
Persentase $(\%)$ & $95,83 \%$ \\
\hline
\end{tabular}

Pada Tabel 4 di atas menunjukkan kemampuan berpikir kreatif matematika aspek fleksibilitas (flexibility) pada soal nomor 4 dengan presentase 95,83\%. Menunjukkan bahwa siswa mampu menghasilkan lebih dari dua jawaban dalam menyelesaikan soal kubus dan balok.

Hasil analisis data kreativitas matematika yang mencakup kelancaran (fluency), fleksibilitas, dan Kebaruan (originality) pada siswa kelas VIII Unggulan MTsN 1 Makassar di atas menunjukkan bahwa hasil yang maksimal, dimana nilai persentase kemampuan berpikir kreatif matematika dari keempat soal materi kubus dan balok tersebut berada diatas 50\%. Pada indikator kelancaran (fluency), siswa dapat menyelesaikan soal dengan menghasilkan minimal 2 jawaban yang berbeda dan benar. Dari kedua soal baik soal nomor 2 dan 4 yang merupakan bagian dari indikator kelancaran hampir semua siswa menyelesaikan soal secara sempurna kecuali pada soal nomor 4 dimana ada 1 orang siswa yang masih kurang disebabkan ada sedikit kesalahan dalam memberikan jawaban yang benar yang berakibat pada nilai yang dikurangi.

Aspek fleksibilitas dan kebaruan (originality) pada soal nomor 1 dan 3 berdasarkan tabel 1 dan 3 di atas menunjukkan kemampuan berpikir kreatif siswa sebagai berikut:

Pada aspek fleksibilitas jawaban soal nomor 1, keenam siswa yang menjadi subyek terdapat 5 siswa mampu menghasilkan jawaban/gagasan alternatif dan kesesuaian jawaban yang diberikan sesuai dengan masalahnya dan benar, adapun 1 siswa lainnya masih melakukan sedikit kesalahan dalam menghasilkan jawaban yang sesuai masalahnya menyebabkan nilai yang diperoleh menurun. Hal tersebut di atas dapat dikatakan bahwa kemampuan berpikir 
kreatif siswa pada aspek fleksibilitas masih sangat tinggi karena secara rata-rata nilai persentasinya berada pada $95,83 \%$. Adapun aspek fleksibilitas pada soal nomor 3 , terdapat 2 siswa yang melakukan sedikit kesalahan dalam menghasilkan jawaban /gagasan alternatif dan kesesuaian jawaban yang diberikan sesuai dengan masalahnya dan benar. Dari kedua siswa tersebut masih melakukan kesalahan yang sama seperti pada soal nomor satu, yang berarti bahwa siswa tersebut kurang baik dalam mununjukkan aspek fleksibilitas. Akan tetapi secara rata-rata nilai persentase dari aspek fleksibilitas masih sangat bagus yaitu 91,67\%

Adapun pada aspek kebaruan (originality) baik pada soal nomor 1 maupun nomor 3 menunjukkan bahwa rata-rata nilai persentasinya paling rendah dari indikator kelancaran (fluency) dan fleksibilitas dengan nilai persentasi masing-masing 75\% (soal nomor 1) dan $70,83 \%$ (soal nomor 2). Siswa sangat kurang dalam menemukan cara-cara baru dalam menghasilkan alternatif jawaban yang benar, kesalahan-kesalahan yang dilakukan cukup banyak dan hanya sedikit kesesuaian jawaban dengan masalah yang diberikan. Dari keenam siswa tersebut hanya 1-2 siswa saja yang mampu menghasilkan jawaban yang tidak biasanya dan kesesuaian jawaban yang diberikan sesuai dengan masalahnya dan benar.

\section{KESIMPULAN}

Penelitian yang dilakukan pada siswa kelas VIII Unggulan MTsN 1 Makassar materi kubus dan balok dapat disimpulkan bahwa hasil penelitian menunjukkan bahwa kemampuan berpikir kreatif matematika siswa mencakup ketiga indikator tersebut sangat bagus berdasarkan nilai persentasi dari masing-masing indikator berada diatas 50\%. Pada indikator kelancaran nilai persentasenya sebesar $100 \%$ soal nomor 1 dan $95,83 \%$ soal nomor 2 , nilai persentase indikator fleksibilitas pada soal nomor 2 dan 4 masing-masing adalah 95,83\% dan 91,67\%, dan nilai persentase indikator kebaruan pada soal nomor 2 dan 4 masing-masing adalah $75 \%$ dan 70,83\%. Dari ketiga indikator di atas, nilai persentase kemapuan berpikir kreatif siswa rendah jika dibandingkan kedua indikator lainnya, hal ini menunjukkan bahwa siswa kurang mampu dalam menghasilkan jawaban/gagasan yang tidak biasanya dan kesesuaian jawaban yang diberikan sangat tidak relevan dengan masalahnya. 


\section{REKOMENDASI}

Guru-guru dapat menggunakan tugas / tes kemampuan berpikir kreatif matematika kepada siswa dalam menyelesaikan solusi dari permasalahan/soal-soal matematika yang didesain dalam bentuk masalah matematika dengan mengacu pada indikator-indikator kemanpuan berpikir kreatif untuk mengasah kemampuan berpikir terbukanya.

\section{UCAPAN TERIMAKASIH}

Penulis menyampaikan ucapan terima kasih kepada Kepala Sekolah MTsN 1 Makassar yang telah memberikan untuk melakukan penelitian. Ucapan terima kasih juga disampaikan kepada Guru Matematika kelas VIII karena sudah memberikan ijin untuk melaksanakan penelitian di kelas VIII Unggulan. Tak lupa ucapan terima kasih secara khusus kepada siswasiswa kelas VIII Unggulan MTsN 1 Makassar yang telah membantu terlaksananya kegiatan penelitian ini.

\section{REFERENSI}

Amidi, A., \& Zahid, M. Z. (2017). Membangun Kemampuan Berpikir Kreatif Matematis Dengan Model Pembelajaran Berbasis Masalah Berbantuan E-Learning. In PRISMA, Prosiding Seminar Nasional Matematika (pp. 586-594).

Arista, E. D. W., \& Mahmudi, A. (2020). Kemampuan berpikir kreatif matematis dalam penyelesaian soal open-ended jenis PISA berdasarkan level sekolah. Pythagoras: Jurnal Pendidikan Matematika, 15(1), 87-99.

Darwanto, D. (2019). Kemampuan Berpikir Kreatif Matematis. Eksponen, 9(2), 20-26.

Dewi, S. S. S., \& Afriansyah, E. A. (2018). Kemampuan Komunikasi Matematis Siswa Melalui Pembelajaran CTL. JIPMat, 3(2), 145-155.

Fardah, D. K. (2012). Analisis proses dan kemampuan berpikir kreatif siswa dalam matematika melalui tugas open-ended.Kreano, Jurnal Matematika KreatifInovatif, 3(2), 91-99. 
Jumramiatun, J., Sowanto, S., \& Mikrayanti, M. (2020). ANALISIS KESULITAN SISWA DALAM MENYELESAIKAN SOAL CERITA PADA POKOK BAHASAN PROGRAM LINEAR. SUPERMAT (Jurnal Pendidikan Matematika), 4(2), 45-62.

Meika, I., \& Sujana, A. (2017). Kemampuan berpikir kreatif dan pemecahan masalah matematis siswa SMA.JPPM (Jurnal Penelitian dan Pembelajaran Matematika), 10(2).

MIKRAYANTI, M. (2020). PENGARUH PEMBELAJARAN KOOPERATIF TIPE JIGSAW TERHADAP PENINGKATAN HASIL BELAJAR SISWA. SUPERMAT (Jurnal Pendidikan Matematika), 4(1), 33-39.

Mulyadin, E., Sowanto, S., \& Dusalan, D. (2020). Pengembangan Perangkat Pembelajaran CIRC (Cooperative Integrated Reading and Composition) dalam Meningkatkan Pemahaman Matematis Pada Materi Perbandingan Siswa SMP. SUPERMAT (Jurnal Pendidikan Matematika), 4(1), 40-51.

Rudyanto, H. E. (2016). Model discovery learning dengan pendekatan saintifik bermuatan karakter untuk meningkatkan kemampuan berpikir kreatif. Premiere Educandum: Jurnal Pendidikan Dasar dan Pembelajaran, 4(01).

Susilawati, S., Pujiastuti, H., \& Sukirwan, S. (2020). Analisis Kemampuan Berpikir Kreatif Matematis Ditinjau Dari Self-Concept Matematis Siswa. Jurnal Cendekia: Jurnal Pendidikan Matematika, 4(2), 512-525.

Ulandari, N., Putri, R., Ningsih, F., \& Putra, A. (2019). Efektivitas model pembelajaran inquiry terhadap kemampuan berpikir kreatif siswa pada materi Teorema Pythagoras. Jurnal Cendekia: Jurnal Pendidikan Matematika, 3(2), 227-237. 